\title{
GROWTH RATES OF DIFFERENT WINE BRANDS OF NISARGA WINERY- A CASE STUDY
}

\author{
Pavitra Balundagi ${ }^{1}$ \\ ${ }^{1}$ Department of Agricultural Economics, Mahatma Phule Krishi Vidyapeeth, Rahuri- 413722 \\ (Maharashtra) \\ Dr. G. G. Joshi ${ }^{2}$ \\ ${ }^{2}$ Department of Agricultural Economics, Mahatma Phule Krishi Vidyapeeth, Rahuri- 413722
}

(Maharashtra)

Article DOI: $\underline{\text { https://doi.org/10.36713/epra6144 }}$

\begin{abstract}
The government of Karnataka has announced wine policy, as result of which many wine yards were established. Nisarga winery in Vijaypur district was one such unit. The specific objectives of the study are to estimate the growth rates in production and sale of different wines and to study per liter production cost of different wines. The primary data for the year 2017-18 was collected from the general manager of the unit. The growth rate analysis, descriptive statistics were used for the study. The Compound annual growth rate of production of Nisarga winery was 1.94 which was non-significant whereas its 1.86 for sale which was significant @ 1 per cent.

KEYWORDS : Growth rates, Production cost
\end{abstract}

\section{INTRODUCTION}

1.1 General

Historically, grapevine (Vitis vinifera L.) is grown mostly for wine making in the world over. In
India on the contrary, remarkable success has been achieved in table grape production and yield levels of fresh grapes are highest in the world.

Table 1.1 Major Grape producing countries in the World (2010)

\begin{tabular}{|c|c|c|c|c|}
\hline Country & Area(ha) & Production(tonnes) & Productivity(tonnes) & $\begin{array}{c}\text { Per cent share of } \\
\text { world in } \\
\text { Production }\end{array}$ \\
\hline China & 533137 & 8651831 & 134263 & 12.89 \\
\hline Italy & 777500 & 7787800 & 59316 & 11.60 \\
\hline USA & 8001 & 6777730 & 195000 & 10.10 \\
\hline Spain & 14942 & 6107200 & 174616 & 9.10 \\
\hline France & 787133 & 5848960 & 100997 & 8.71 \\
\hline Turkey & 19000 & 4255000 & 15625 & 6.34 \\
\hline Chile & 188220 & 2755700 & 162282 & 4.11 \\
\hline Argentina & 223685 & 2616610 & 116977 & 3.90 \\
\hline
\end{tabular}

(C) 2021 EPRA ARER । www.eprajournals.com । Journal DOI URL: https://doi.org/10.36713/epra0813 
EPRA International Journal of Agriculture and Rural Economic Research (ARER)- Peer-Reviewed Journal Volume: 9 | Issue: 1| January 2021 | Journal DOI: 10.36713/epra0813|Impact Factor (SJIF): 7.367| ISSN: 2321 - 7847

\begin{tabular}{|c|c|c|c|c|}
\hline Iran & $\mathbf{2 2 0 8 3 6}$ & $\mathbf{2 2 5 5 6 7 0}$ & $\mathbf{1 0 0 1 6 5}$ & $\mathbf{3 . 3 6}$ \\
\hline Australia & $\mathbf{1 6 3 7 8 5}$ & $\mathbf{1 6 8 4 3 5 0}$ & $\mathbf{1 0 2 8 3 9}$ & $\mathbf{2 . 5 1}$ \\
\hline Other countries & $\mathbf{4 1 6 8 2 9 3}$ & $\mathbf{1 8 3 7 5 4 0 4}$ & $\mathbf{6 5 7 5 0 4 7}$ & $\mathbf{2 7 . 3 8}$ \\
\hline World total & $\mathbf{7 1 0 4 5 1 2}$ & $\mathbf{6 7 1 1 6 2 5 5}$ & $\mathbf{7 7 3 7 1 2 7}$ & $\mathbf{1 0 0 . 0 0}$ \\
\hline
\end{tabular}

Source: FAO data (2010)

According to the table FAO data (2010) shows that, the leading grape producing countries in the world in terms of production are China (8651.83 thousand tons), Italy (7787.80 thousand tons), USA (6777.73 thousand tons) and Spain (6107.20 thousand tons). India's high productivity in grape has made it to reach $18^{\text {th }}$ position in the world as far as production is concerned.

Table 1.2 Top grape producing countries in India (2016-17)

\begin{tabular}{|c|c|c|c|}
\hline States & $\begin{array}{c}\text { Area } \\
\text { ('000 ha) }\end{array}$ & $\begin{array}{c}\text { Production } \\
\text { ('000 MT) }\end{array}$ & $\begin{array}{c}\text { Productivity } \\
\text { (In } \text { MT/Ha) }\end{array}$ \\
\hline Maharashtra & 90.36 & 2074.02 & 18.40 \\
\hline Karnataka & 24.23 & 445.89 & 20.00 \\
\hline Andhra Pradesh & 0.83 & 16.62 & 13.27 \\
\hline Tamil Nadu & 2.44 & 34.10 & 28.39 \\
\hline Punjab & 0.30 & 8.49 & 5.16 \\
\hline Haryana & 0.04 & 0.20 & 2.11 \\
\hline Uttar Pradesh & 0.02 & 0.10 & 3.00 \\
\hline Rajasthan & 0.01 & 0.02 & $\mathbf{1 5 . 0 0}$ \\
\hline Madya Pradesh & $\mathbf{0 . 1 6}$ & $\mathbf{3 . 0 0}$ & $\mathbf{1 9 . 7 4}$ \\
\hline Total in India & $\mathbf{1 2 2 . 8 8}$ & $\mathbf{2 6 3 4 . 7 4}$ & \\
\hline
\end{tabular}

Source: www.Indiastat.com (2018)

Table 1.2 shows that Maharashtra, Karnataka and Andhra Pradesh hold first, second and third position in the country in production, productivity and area of grapes. In India during 2016-17 Total area under grapes was 122.00 thousand hectares, production was 2634.74 thousand metric tonnes and productivity was 19.74 metric tonnes.

Table 1.3 Area, production and productivity of Grapes in Karnataka

\begin{tabular}{|c|c|c|c|}
\hline Years & $\begin{array}{c}\text { Area } \\
\text { ( ha) }\end{array}$ & $\begin{array}{c}\text { Production } \\
\text { (In tonnes) }\end{array}$ & $\begin{array}{c}\text { Productivity } \\
\text { (Kgs/Ha) }\end{array}$ \\
\hline $2004-05$ & 9406 & 243329 & 25869 \\
\hline $2005-06$ & 5903 & 176796 & 29950 \\
\hline $2006-07$ & 11991 & 327513 & 27313 \\
\hline $2007-08$ & 10029 & 265199 & 25221 \\
\hline $2008-09$ & 12894 & 325199 & 31254 \\
\hline $2009-10$ & 12221 & 381955 & 39926 \\
\hline $2010-11$ & 13634 & 544351 & 43035 \\
\hline $2011-12$ & 15678 & 674703 & $\mathbf{4 4 8 0 5}$ \\
\hline $2012-13$ & $\mathbf{1 8 3 4 8}$ & 822085 & $\mathbf{3 7 3 5 5}$ \\
\hline $2013-14$ & $\mathbf{1 8 1 8 7}$ & $\mathbf{6 7 9 3 7 8}$ & \\
\hline
\end{tabular}

Source: www.indiastat.com

Table 1.3represents that There is an increase in Area under grape production in Karnataka from
2001-05 to 2013-14 and in production and productivity no constant increase or decrease rates.

(c) 2021 EPRA ARER ｜ www.eprajournals.com ｜ Journal DOI URL: https://doi.org/10.36713/epra0813 
Apart from this According to the report given from Gus trompiz in Business insider in 2017, in overall concern Production in Australia was expected to rise 6 per cent to 13.9 million hectoliters while Argentina was projected to post a 25 per cent jump to 11.8 million after a weather hit.

\section{$1.2 \quad$ Nisarga Wine Industry Vijaypur}

This Nisarga vineyard Pvt. Ltd is established in the year 2009-10 and it is located at Halagani village, adjacent to highway connecting the Vijaypur and Belgaum town and is just $25 \mathrm{~km}$ away from Vijaypur city limits measuring five acres. The unit will produce both White wine and Red wine. There are total seven brands under the process. The production has been started in the year 2010 with a production of 386075 liters and in 2017-18 it is 358851 liters.

\section{METHODOLOGY}

\subsection{Selection of the Study Area}

The choice of Vijaypur district of North

Karnataka was purposive, as more grape wineries were located and the huge area is under grape cultivation. Hence Nisarga wine industry is selected as it has better economic feasibility and profitable margin.

\subsection{Collection of Data}

Secondary data for the year 2017-18 regarding the Production, sales, financial information, production and marketing cost of the Grape wines was collected by survey method through personal interview with the manager of unit with the help of presented questionnaire.

The efforts were made to prepare report with the manager through the personal assistance of owner and other supervisors. The data were collected in January 2019.

\subsection{Sources of Data}

The study contemplates to assess the performance of Wine unit in Vijaypur Dist. of Karnataka. Obviously, the data were required on various factors of different wines which were being produced in that unit.

\section{The major aspects of data requirements were as under:}

1. Primary information of the unit.

2. Details of production and sale of grape wine.

3. Initial investment of the unit.

4. Fixed and operating cost of the unit.

5. Repairs and maintenance cost.

6. Fees, taxes, insurance and other relevant expenses.

7. Labours, supervisory staff and decision makers engaged with their bills, salaries and allowances.
8. Problems encountered by the unit in acquisition of raw materials, production and marketing processes.

Data was collected from the available records, registers of the Nisarga wine industry through discussion with the management.

\subsection{Method of Analysis}

To facilitate the analysis of data, the sample of wine is divided into Red and white with different brands and they are again categorized according to their capacity ranges 750,375 and $180 \mathrm{ml}$.

The data collected from the unit was compiled according to their individual brands. The data so compiled was further analyzed to obtain averages related to different aspects.

\subsubsection{Growth Rate Analysis}

In order to study the trends in wine consumption, to estimate the growth of retail outlets and forecast the demand for Nisarga wine in future the compound growth rate analysis technique is used. The functional form of the compound growth rate analysis is,

$$
\begin{aligned}
& \text { Where, } \begin{aligned}
& \mathrm{Y}=\mathrm{ab}^{\mathrm{t}} \text { eut...................... (1) } \\
& \mathrm{Y}=\text { Dependent variable } \\
& \text { growth rate is estimated } \\
& \mathrm{a}=\text { Intercept } \\
& \mathrm{b}=\text { Regression coefficient } \\
& \mathrm{t}=\text { Time variable } \\
& \text { eut }=\text { Error term }
\end{aligned}
\end{aligned}
$$$$
\mathrm{Y}=\text { Dependent variable for which }
$$

The compound growth rate is obtained from the logarithmic form of the equation (1) as below and it was taken from the report Corporate finance and accounting report given by Chris murphy in 2019 .

$\ln \mathrm{Y}=\ln \mathrm{a}+\mathrm{t} \ln \mathrm{b}+\mathrm{Ut}$

The per cent compound growth rate $(\mathrm{g})$ is derived using the relationship, $\mathrm{g}=($ Anti $\ln$ of $\mathrm{b}-1) \times 100$

Pattern of growth rates over the years was identified using the ' $b$ ' coefficient. If coefficient was statistically significant and positive then growth of the estimated parameters over the years was accelerating. If it is negative, it was implied that, growth was decelerating over the year.

\section{RESULT DISCUSSION}

The activity that is processing of grapes into wine being an important economic aspect in realizing the better price for the Agricultural product, the study of economic evaluation of Nisarga wine industry becomes an important activity. To study performance evaluation and managerial aspects of the unit some results were discussed below. In this chapter the economic performance of Nisarga Wine was studied. Therefore, an attempt has made in this chapter to study 
the different objectives of the Wine unit which were enlisted below.

The results of the study are discussed in this chapter as under the following headings.

4.1 The growth rates in production and sales of grape wine.
4.1 The Growth Rates in Production and Sales of Grape Wine

4.1.1 Production of Grape Wine by Nisarga Winery

The information on Production of grape wine is depicted in the Table 4.1.

Table 4.1 Production of Red and White wine with combined total quantity

\begin{tabular}{|c|c|c|c|}
\hline \multirow{2}{*}{ Year } & \multicolumn{2}{|c|}{ Production ('000 liters) } & \multirow{2}{*}{ Total ('000 liters) } \\
\cline { 2 - 3 } & Red Wine & White Wine & \\
\hline $2010-11$ & $3,08,860$ & 77215 & 386075 \\
\hline $2011-12$ & 369542.4 & 92385.06 & 461928 \\
\hline $2012-13$ & 279434.4 & 69858.6 & 349293 \\
\hline $2013-14$ & 300362.4 & 75090.6 & 375453 \\
\hline $2014-15$ & 290422.4 & 72605.6 & 363028 \\
\hline $2015-16$ & 251854.4 & 62963.6 & 314818 \\
\hline $2016-17$ & 315716.8 & 78929.2 & 394646 \\
\hline $2017-18$ & 287080.8 & 71770.2 & 358851 \\
\hline CAGR & $\mathbf{1 . 2 7 N S}$ & $\mathbf{0 . 6 7 N S}$ & $\mathbf{1 . 9 4 N S}$ \\
\hline
\end{tabular}

$(*, * *, * * * @ 10 \%, 5 \%$ and 1\% level of significance)

The production unit was established in the year 2009 , it was observed from the table that the production started from the year 2010-11 with wine production of 386075 liters and in the year 2017-18 production is 358851 liters. After the establishment of the Nisarga winery the production was decreased up to 2014 due to lack of market potential and then started increasing.

Here the estimated CAGR was 1.27 for Red wine and 0.67 for White wine and both are showing non-significant rate and the CAGR vale for total production was 1.94 which is also non-significant one.

\subsubsection{Sale of Grape Wine by Nisarga Winery}

The information related to sales of grape wine is presented in Table 4.2.

In 2009 when the unit was started, there was no sale in 2010. The amount of sale was 371928 liter. As the Nisarga wine is new to the market, the sales have been decreased to 296362 liters in 2011. As per the market demand of Nisarga wine sales has increased where we can say that in 2013 the sales were at 319153 liters.

Table 4.2 Sales of grape wine

\begin{tabular}{|c|c|c|c|}
\hline \multirow{2}{*}{ Year } & \multicolumn{2}{|c|}{ Sale ('000 liters) } & \multirow{2}{*}{ Total ('000 liters) } \\
\cline { 2 - 3 } & Red Wine & White Wine & \\
\hline $2010-11$ & 297542.4 & 74385.6 & 371928 \\
\hline $2011-12$ & 237089.6 & 59272.4 & 296362 \\
\hline $2012-13$ & 255322.4 & 63830.6 & 319153 \\
\hline $2013-14$ & 280022.4 & 70005.6 & 350028 \\
\hline $2014-15$ & 249134.4 & 62283.6 & 311418 \\
\hline $2015-16$ & 165844.8 & 41461.2 & 207306 \\
\hline $2016-17$ & 194854.4 & 48713.6 & 243568 \\
\hline $2017-18$ & 150773.6 & 37693.4 & 188437 \\
\hline CAGR & $\mathbf{1 . 1 3}^{* * *}$ & $\mathbf{0 . 7 3}^{* * *}$ & $\mathbf{1 . 8 6}$ *** \\
\hline
\end{tabular}

$(*, * *, * * * @ 10 \%, 5 \%$ and $1 \%$ level of significance) 


\subsubsection{Compound Annual Growth rates of} Production and Sales of Nisarga winery
The information regarding Compound Annual Growth Rates of Production and Sales of Nisarga wine is represented in Table 4.3.

Table 4.3 Growth rates of Nisarga winery (2009-2018)

\begin{tabular}{|l|c|}
\hline & Annual CGR \\
\hline Production & $1.94 \mathrm{NS}$ \\
\hline Sale & $1.86^{* * *}$ \\
\hline
\end{tabular}

$(*, * *, * * * @ 10 \%, 5 \%$ and $1 \%$ level of significance)

\section{Production of different wines over the years(2010-18)}
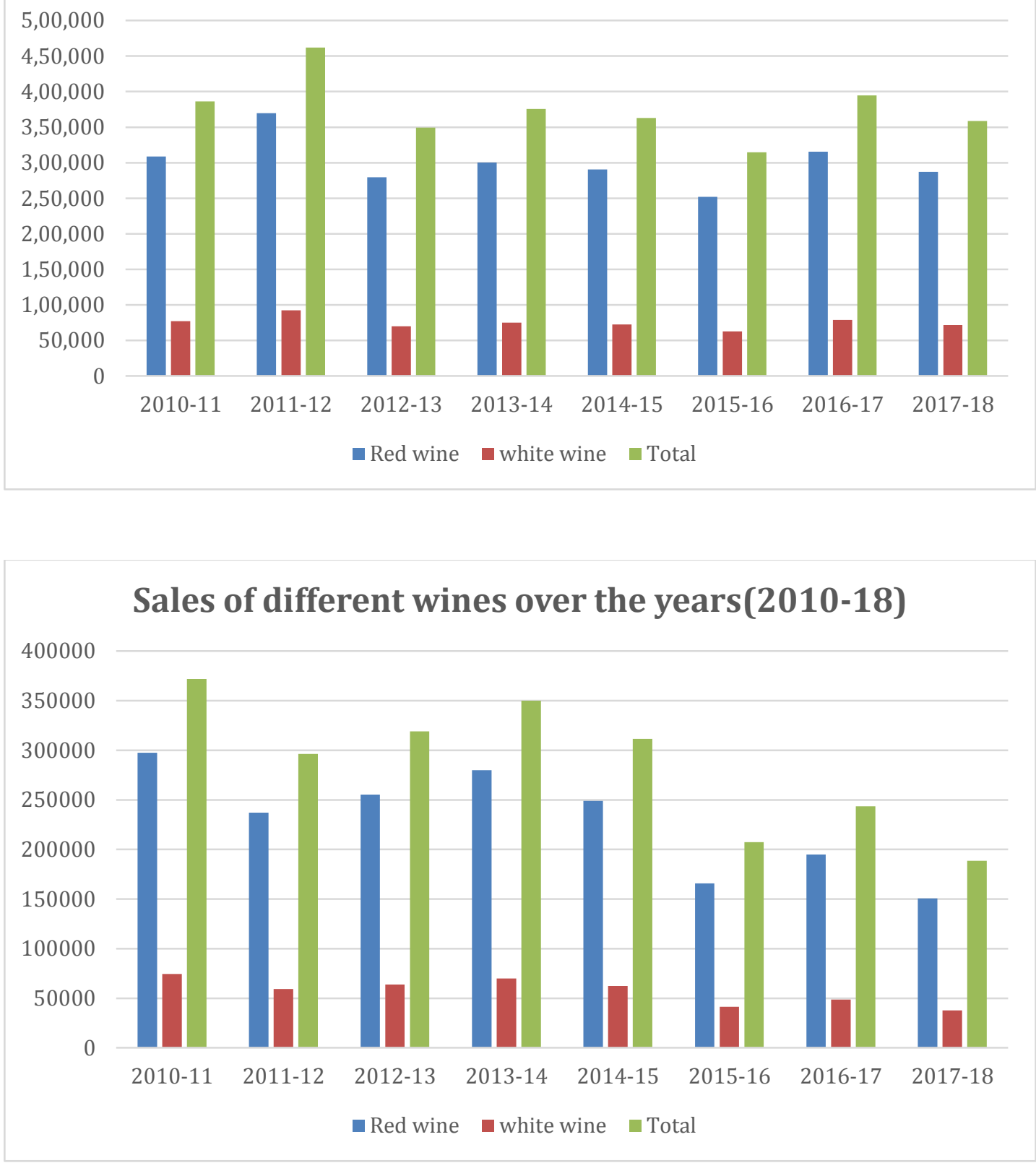

(c) 2021 EPRA ARER | www.eprajournals.com | Journal DOI URL: https://doi.org/10.36713/epra0813 
It is observed that Compound growth rate of production is 1.94 per cent and it is showing non-significance as there was no accelerating growth. For sales it is showing 1.86 percentage with significant growth at 1 per cent.

\section{COCLUSIONS}

1. The Nisarga winery firm started in 2009 produced grape wine of 386075 liters in 2010-11 which was 358851 in 2017-18. The compound annual growth rate of production of Nisarga wine worked out to be 1.94 per cent (NS) [Red wine $1.27 \mathrm{NS}$ and white wine $0.67 \mathrm{NS})$. The sale of the Nisarga winery increased was 371928 liters in 201011 to 188437 liters in 2017-18 recording a compound annual growth rate of 1.86 per cent $[1.13$ per cent for Red wine and 0.73 per cent for white wine]. Around 96 per cent of wine produced was sold in the same year. The efficiency of resource use is 1.5 Kilogram og Grapes are required to produce one litre of wine i.e., 1 kilo gram of Grape gives 0.67 litres of Wine in this industry.

2. Nisarga winery offer 7 different brands of wine which comprises both red wine as well as the white wine. The brand names of the Nisarga winery are Nisarga, Samurai and Viraat. Cost amounted from the raw materials for red wine is ₹ 194.71 lakhs and for white wine it is ₹ 49.13 lakhs. Total cost amounted from raw materials for production of both red and white wine is ₹ 243.84 lakhs.In total wine production share of red wine was maximum i.e., 287 thousand liters (79.94\%) followed by white wine i.e. 72 thousand liters $(20.05 \%)$. Total production of wine from both red and white wine is 359 thousand liters.

\section{REFERENCE}

1. Alexander, E. and Ellinger. 2011. Supply Chain Management Competency and Firm Financial Success. Journal of Business Logistics, 32 (3).

2. Anderson, K. andWittwer.G. 2015. Asia's evolving role in global wine markets. Chinas economic review, 35: 1-14.

3. Andriotis. 2008. Measuring tourist satisfaction, A factor cluster segmentation approach. Journal of vacation marketing, 14(3): 221-235.

4. Castaldi, M.A. and Folwell. R.J. 1985. Economic returns and impacts: An historical perspective. Chris, M.2019. Corporate finance and accounting

5. Das, K. 2010. Prospects and Challenges of Geographical Indications in India. The Journal of World Intellectual Property.
6. Vivekanand, P.P. 2014. Business performance analysis of Nisarga wines in Vijaypur district. Unpublished thesis university of agricultural sciences, Bangalore.

7. Yirga, G. and Tefe, M. 2010, Participatory Technology and Constraints Assessment to Improve the Livelihood of Beekeepers in Tigray Region, northern Ethiopia. Momona Ethiopian Journal of Science, 2 (1).

\section{Webliography}

1. www, avensonline.org

2. www.sulawines.com

3. www.indiastat.com

4. www.apeda.com

5. www.sciencedirect.com

6. National horticulture board

7. $F A O$

8. www.karnatakawineboard.com

(c)21 EPRA ARER | www.eprajournals.com | Journal DOI URL: https://doi.org/10.36713/epra0813 